\title{
Partial Androgen Deficiency, Depression, and Testosterone Supplementation in Aging Men
}

\author{
Mario Amore, ${ }^{1}$ Marco Innamorati, ${ }^{1}$ Sara Costi, ${ }^{1}$ Leo Sher, ${ }^{2}$ \\ Paolo Girardi, ${ }^{3}$ and Maurizio Pompili ${ }^{3}$ \\ ${ }^{1}$ Department of Neurosciences, Institute of Psychiatry, University of Parma, Piazza Matteotti 9, 43100 Parma, Italy \\ ${ }^{2}$ Department of Psychiatry, Mount Sinai School of Medicine, New York, NY 10029, USA \\ ${ }^{3}$ Department of Neurosciences, Mental Health and Sensory Organs, Suicide Prevention Center, Sant'Andrea Hospital, \\ Sapienza University of Rome, 00189 Rome, Italy \\ Correspondence should be addressed to Mario Amore, mario.amore@unipr.it \\ Received 13 January 2012; Revised 8 April 2012; Accepted 10 April 2012 \\ Academic Editor: Huan Cai
}

Copyright ( $\odot 2012$ Mario Amore et al. This is an open access article distributed under the Creative Commons Attribution License, which permits unrestricted use, distribution, and reproduction in any medium, provided the original work is properly cited.

The aim of this review was to summarize current knowledge on the correlation between depressive symptoms with a syndrome called partial androgen deficiency of the aging male (PADAM) and on the potential benefits of testosterone (T) treatment on mood. Despite, the causative nature of the relationship between low $\mathrm{T}$ levels and depression is uncertain, many hypogonadal men suffer from depression and vice versa several depressed patients are affected by hypogonadism. Supplementation with testosterone failed to show sound evidence of effectiveness in the treatment of depression. Nevertheless, testosterone supplementation has proved to be effective on some domains significant for the quality of life of aged patients with PADAM (sexual function and cognitive functions, muscular strengths).

\section{Introduction}

Testosterone deficiency or hypotestosteronemia is a widely recognized hormonal alteration associated with male aging [1-3]. Its prevalence may be as high as $30 \%$ in men aged $40-$ 79 years $[4,5]$, and in up to $12 \%$ the hypotestosteronemia it can be associated with clinical symptoms [5]. Nevertheless, different levels of testosterone $(\mathrm{T})$ could be associated with the presence of specific clinical symptoms [6,7].

The joint consensus of International Society of Andrology, the International Society for the Study of the Aging Male (ISSAM) and the European Association of Urology prepared a set of recommendations specifically on the Investigation, treatment, and monitoring of late-onset hypogonadism in males $[8,9]$. Laboratory diagnosis of hypogonadism is based on the measurement of serum total testosterone (TT). Although there is no uniformly accepted threshold level for $\mathrm{T}$ in older men, TT levels above $350 \mathrm{ng} / \mathrm{dL}$ are considered normal and do not require substitution therapy, while TT levels below $230 \mathrm{ng} / \mathrm{dL}$ usually benefit from testosterone treatment. When TT level is between 230 and $350 \mathrm{ng} / \mathrm{dL}$, it may be useful to calculate free testosterone (FT), particularly in obese men. FT level below $65 \mathrm{pg} / \mathrm{mL}$ suggests that testosterone treatment is needed $[10,11]$.

In 2010, the Endocrine Society published clinical practice guidelines for testosterone therapy in adult men with androgen deficiency syndrome [12]. The members of the working group agreed that because the normative ranges for TT and FT in healthy young men vary among laboratories and assays (lower TT limits: 280-300 ng/dL; lower FT limits: 5-9 pg/ $\mathrm{mL}$ ) [13], clinicians should use the lower limit of normal range for healthy young men established in their laboratory. Members of the working group disagreed on $\mathrm{T}$ concentrations below which testosterone supplementation should be offered to older men with symptomatic hypogonadism. Some members of the working group recommended T supplementation in older men with TT level below $300 \mathrm{ng} / \mathrm{dL}$, because this is the threshold at which older men have 
symptoms that might be attributable to low testosterone; others recommended $\mathrm{T}$ supplementation only in those with TT level below $200 \mathrm{ng} / \mathrm{dL}$, because higher pretreatment T values are associated with lower beneficial effects of $\mathrm{T}$ therapy.

Age-related serum testosterone decline is caused by different simultaneous mechanisms, such as primary structural gonadal impairment, age-related degenerative modifications of the pituitary gland, deficits of the neurohypothalamic system, and primary peripheral metabolic abnormalities such as the age-associated increase in the concentration of serum sex hormone binding globulin (SHBG), with a consequent decrease in FT [3].

It is controversial whether aging is to be considered as the only variable linked to age-related $\mathrm{T}$ decline $[14,15]$ : several factors do seem to interfere in different ways with $\mathrm{T}$ metabolism, like genetic factors [16], chronic diseases [17-19], chronic medications [20], obesity [7, 21, 22], and lifestyle factors $[23,24]$.

Despite the fact that many men with low testosterone levels are asymptomatic [25], many others have a partial, gradual, and variable decline in $\mathrm{T}$ associated with various clinical symptoms, described as a syndrome called partial androgen deficiency of the aging male (PADAM) [26]. PADAM is characterized by sexual, somatic, and behavioral symptoms, with insidious onset and slow progression [27]: diminished sexual desire and erectile quality, particularly nocturnal erections [28, 29]; decrease in lean body mass, with associated diminution in muscle volume and strength; increase in visceral fat [30-32], decrease in bone mineral density, resulting in osteoporosis [33]; reduction in body hair and skin alterations [34]; weakness, fatigue, depression, lack of motivation and energy, lower psychological vitality, anxiety, irritability, insomnia, decreased work and sport performances; difficulty in concentrating, memory impairment, and low dominance [35-41].

In the Endocrine Society Guidelines symptoms are separated into two groups, more specific symptoms and signs of hypogonadism (incomplete or delayed sexual development, sexual disorders, breast discomfort, gynecomastia, loss of body [axillary and pubic] hair, reduced shaving, very small or shrinking testes, inability to father children, low or zero sperm count, height loss, low trauma fracture, low bone mineral density, hot flushes, and sweats) and less specific symptoms (decreased energy, motivation, initiative, self-confidence, feeling sad or blue, depressed mood, dysthymia, poor concentration and memory, sleep disturbance, increased sleepiness, mild anemia, reduced muscle bulk and strength, increased body fat, body mass index, and diminished physical or work performance) [12]. Serum T concentration has to be measured in patients with the more specific symptoms of hypogonadism and considered in those who report the less specific symptoms. The diagnosis of hypogonadism is possible when serum $\mathrm{T}$ level is below lower limits, and reversible illness, drugs, and nutritional deficiency have been excluded.

PADAM as a clinical entity is still controversial, because it is very difficult to distinguish to what extent the symptoms attributed to PADAM are due to the natural and unavoidable consequences of aging and how much to androgen deficiency $[37,42,43]$.

Behavioral aspects of PADAM may overlap with signs of depression. For example, McIntyre et al. [44] considered that reduction in physiologically active bioavailable testosterone (BT) concentration is a vulnerability factor for depressive symptoms in middle-aged depressed men. The authors assessed and compared TT and BT levels in two groups of middle-aged men (40-65 years), untreated subjects meeting DSM-IV-TR (Diagnostic and Statistical Manual of Mental Disorders-4th edition, text revised) [45] criteria for a major depressive episode $(N=44)$, and a matched nondepressed control group $(N=50)$. Depressed men had lower mean BT levels and TT levels than the control group. Biochemical hypogonadism (i.e., BT level $\leq 70 \mathrm{ng} / \mathrm{dL}$ or TT level $\leq 350 \mathrm{ng} / \mathrm{dL}$ ) was also more prevalent in depressed men than in nondepressed controls (34\% versus $6 \% ; 61 \%$ versus $14 \%$, resp.).

Thus, the aim of this review was to summarize current knowledge on depressive symptoms correlated with PADAM and on the potential benefits of $\mathrm{T}$ treatment on mood.

\section{Methods}

In order to provide a critical review of the association of PADAM and depression in older males, we performed a PubMed search to identify all papers published in English peer-reviewed journals between 1980 and 2012. The search string was androgen deficiency OR testosterone deficiency OR hypogonadism OR testosterone treatment OR testosterone supplementation AND depress*.

We limited the search to articles reporting data for male aged 45+ years old. All English full-text articles reporting original data about the main topic were included. The reference lists of the articles included in the review were also manually checked to retrieve other relevant studies.

\section{Results}

3.1. T Levels and Depression. Epidemiological and clinical studies of the connection between age-related low $\mathrm{T}$ levels and a reduced feeling of well-being, with unusual anxiety and irritability, nervousness, mood swings, and a depressive state, have produced mixed results [46-63] (see Tables 1 and 2).

Positive results were reported by Hintikka et al. [47] who examined associations between hypogonadism (laboratory diagnosis was based on FT level $<4.6 \mathrm{ng} / \mathrm{dL}$ ), erectile dysfunction, sexual desire, and long-term and current depressive symptoms in a population-based sample of Finnish middleaged men. The inclusion criteria for this study were based on self-reported adverse mental symptoms prevailing at baseline and at the 3-year followup. At 7 years from the baseline, men who reported long-term adverse mental symptoms had higher depression but lower FT levels than asymptomatic men. Furthermore, depression correlated negatively with FT (rho $=-0.20 ; P<0.05$ ) in the entire sample.

The Rancho Bernardo Study examined the association between $\mathrm{T}$ and depression in 856 community-dwelling older 


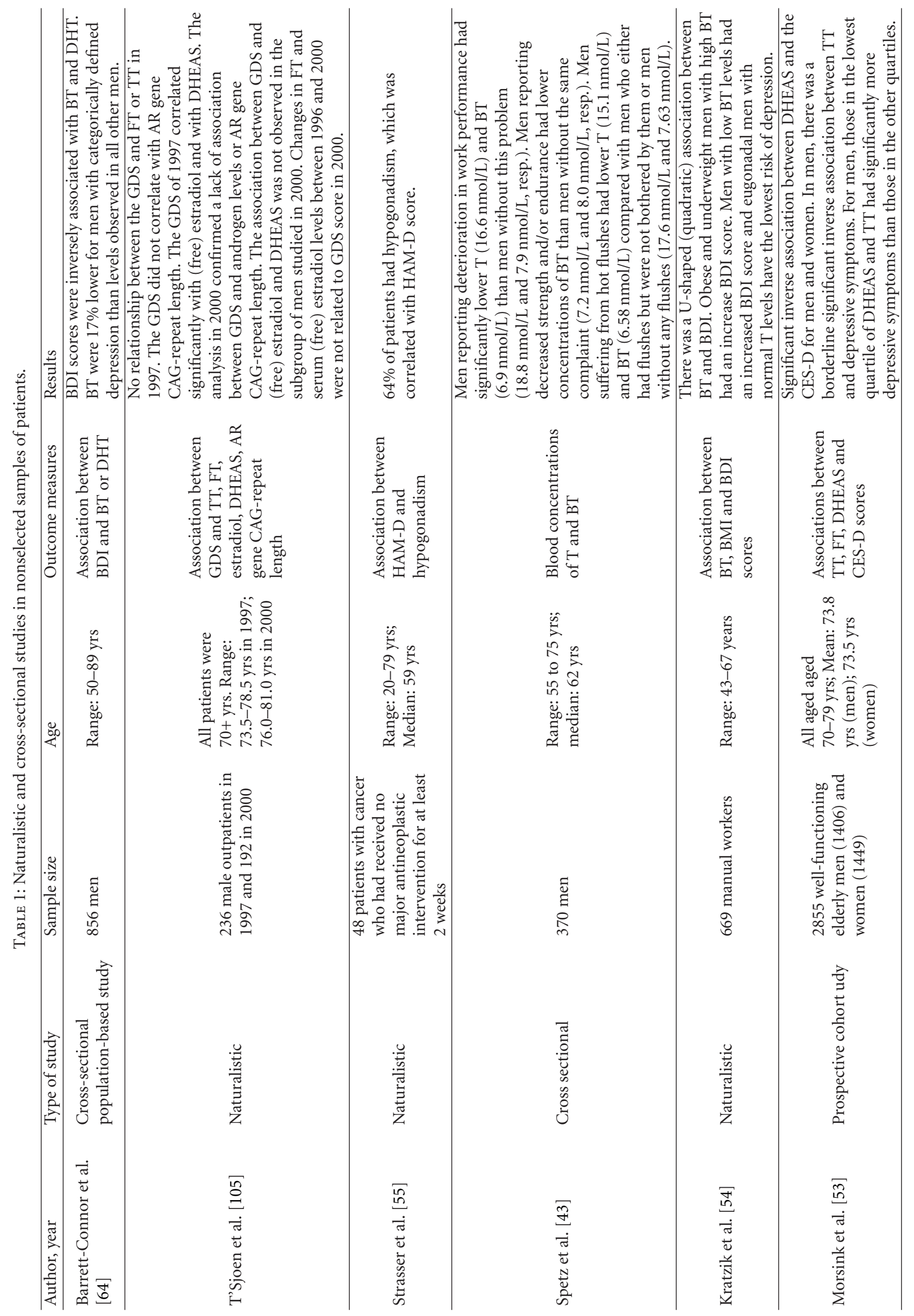




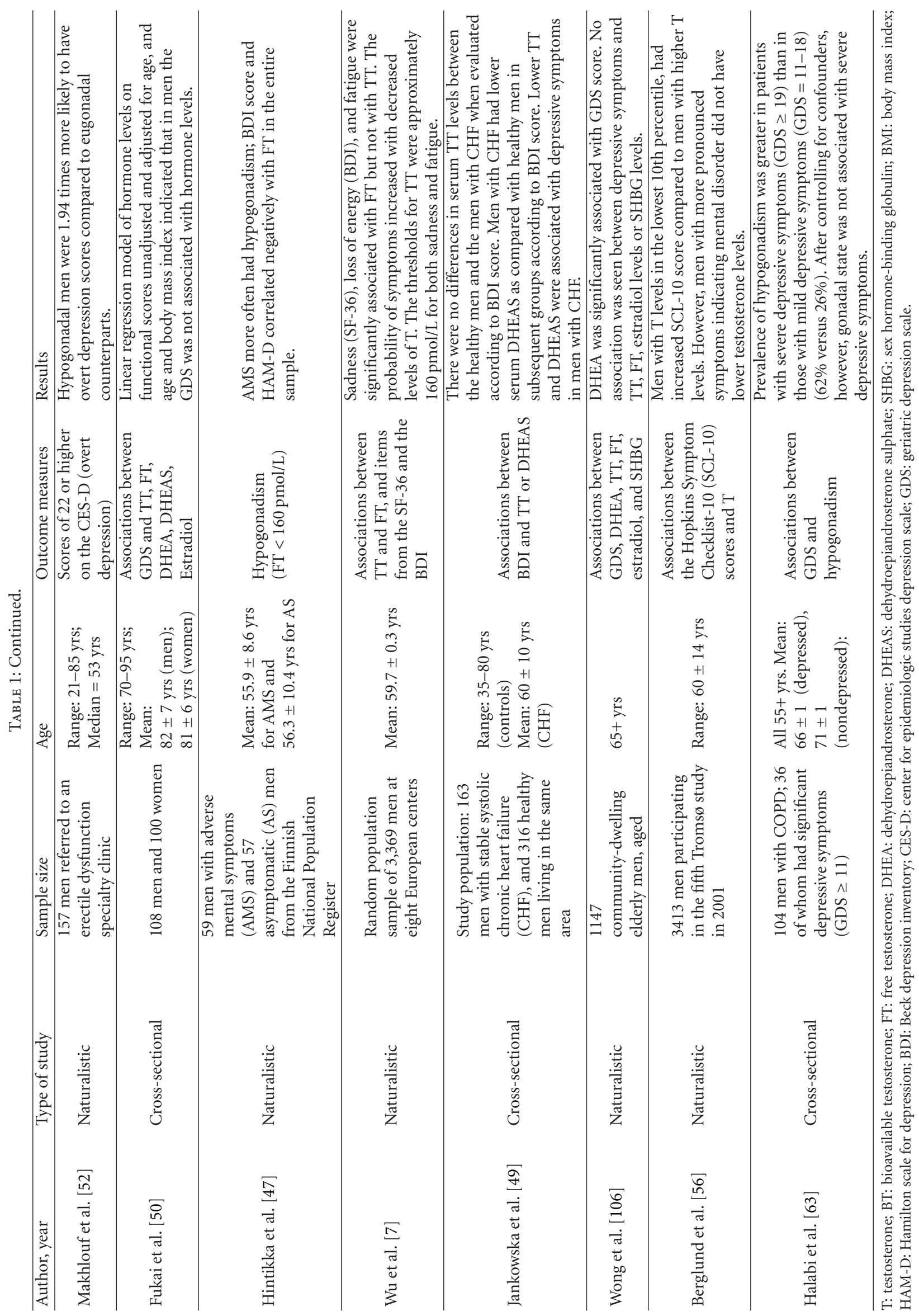




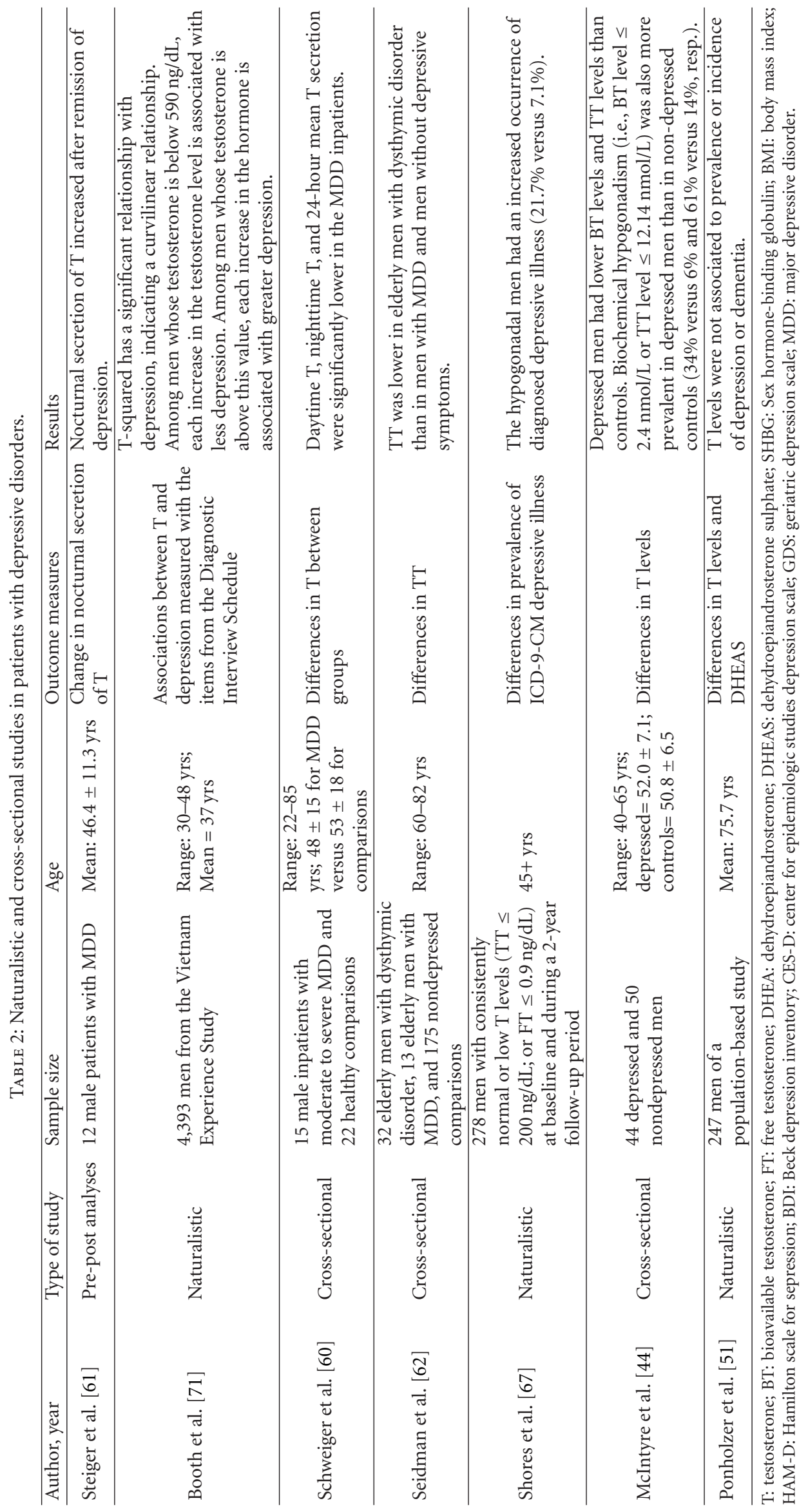


men aged 50 to 89 years (mean age 70.2 years) during a period of 4 years [64]. In that study, BT levels decreased with age and were significantly and inversely associated with Beck Depression Inventory (BDI) scores [65], indicating more depressive symptoms associated with lower BT levels. There was a graded stepwise decrease in BT, with a parallel increasing level of depressed mood; in addition, BT levels were $17 \%$ lower in men with categorically defined depression than in controls.

Lee et al. [66] investigated the PADAM in a community sample of 311 Chinese men (aged 40-80) attending a family medicine clinic in Hong Kong. A total of $87.8 \%$ of the sample was screened PADAM positive using the ADAM questionnaire. PADAM-positive individuals were found to have poorer quality of life, higher depression and anxiety, even after adjusting for age and number of current diseases.

In a historical cohort study, the Veterans Affairs Puget Sound Health Care System carried out on 278 men aged 45 years and older without previous depressive diagnosis, hypogonadal men with TT levels of $200 \mathrm{ng} / \mathrm{dL}$ or less (compared to eugonadal men) showed an approximate 4fold increase in the risk of incident depression in the 2-year followup [67]. The risk of depression was inversely related to $\mathrm{T}$ levels, with statistically significant findings observed at $\mathrm{T}$ levels lower than $280 \mathrm{ng} / \mathrm{dL}$.

In a sample of 32 subjects with dysthymic disorder (mean age 70.5 , SD 5.8, range $=60-82$ years), Seidman et al. [62] found that most elderly men with dysthymic disorder had TT levels in the hypogonadal range (i.e., $\leq 300 \mathrm{ng} / \mathrm{dL}$ ). Furthermore, their TT levels were lower than in patients with MDD or healthy controls. The authors hypothesized that dysthymic disorder in elderly men may be related to HPG axis hypofunction. This association is believed to be the result of either chronic depression leading to HPG axis blunting, or to HPG axis hypofunctioning leading to lowgrade depression [68].

Furthermore, there is some evidence that, compared with controls, $\mathrm{T}$ secretion is blunted among older men with severe major depressive disorder (MDD), it appears to normalize after major depressive episode remission $[60,61]$. A significant increase in depression during the androgen deprivation treatment period, and a tendency to decline after chemical castration was discontinued has been observed in eugonadal men at risk for prostate cancer who are treated with androgen blockade therapy [69].

No association between depression and T level has been reported in the Massachusetts Male Aging Study, a crosssectional, population-based multidisciplinary survey of 1,709 normally aging men (aged 39-70 years) [70]. Partially positive results were also reported more recently in the Tromso Study [56]. In this study, lower testosterone levels were associated with subthreshold symptoms of anxiety and depression. The Veterans' Experience Study [71], which investigated a sample of 4,393 veterans who served the U.S. military (mean age 37 years), found small but significant associations between depression and T Level $(r=0.04 ; P<$ 0.01 ). However, in this latter study, the authors pointed out that the relationship between $\mathrm{T}$ level and depression may actually be curvilinear [71].
The causative nature of the relationship between low $\mathrm{T}$ levels and depression is uncertain. For example, investigators of the Massachusetts Male Aging Study found a significant interaction between polymorphic CAG repeats sequence encoding a variable-length glutamine chain in the $\mathrm{N}$-terminal transactivation domain of an androgen receptor genetic polymorphism protein, testosterone level, and depression [72]. The CAG repeat length appears to have modulatory effects on androgen action [73, 74], and the associations between depression and testosterone concentration may be mediated by different androgen sensitivity. The psychiatric effects of T may be also mediated through modulation of brain monoamine levels and, in particular, of the serotonergic function $[75,76]$. In animal models, $\mathrm{T}$ increases cortical serotonin $2 \mathrm{~A}$ receptor binding densities [77] and, in humans, cortical serotonin $2 \mathrm{~A}$ receptors decrease with depression and aging [78].

3.2. $T$ Treatment of Depression in Older Men. Although the practice of hormone replacement therapy began as long ago as the 18th century, with the use of extractions of reproductive organs of animals to treat a variety of ailments or to enhance the capacity for enjoyment of work and sexual activity [79-81], the role of $\mathrm{T}$ therapy for middle-aged and older men with depression is still uncertain (see Tables 3 and 4). T replacement in hypogonadal males generally decreases anger, nervousness, irritability and anxiety [35], and consistently leads to increased sexual interest and activity ([82, 83], see [84] for negative results).

In a randomized, placebo-controlled, double-blind, phase III trial (ClinicalTrials.gov identifier: NCT00696748), 184 men suffering from both the metabolic syndrome and hypogonadism were treated for 30 weeks with either parenteral testosterone undecanoate (TU; 1,000 mg IM TU) or placebo injections [85]. Depression was assessed at the baseline and at 18 and 30 weeks with the BDI. At baseline, depression significantly correlated with the total testosterone level $(r=-0.16 ; P=0.03)$. When comparing the changes over time in patients treated with TU versus the placebo group, there was a significant improvement in depression (mean difference versus placebo after 30 weeks: -2.5 points; 95\% CI: $-0.9 ;-4.1 ; P=0.003)$. Effects were strongest in men with the lowest baseline total testosterone $(<222 \mathrm{ng} / \mathrm{dL})$.

In a sample of 51 hypogonadal men (aged 22 to 60 years) studied for 60 days, $T$ replacement improved positive mood parameters, such as energy, well-being and friendliness, and decreased negative mood parameters including anger, nervousness, and irritability [35]. Direct correlations between serum $\mathrm{T}$ and dihydrotestosterone (DHT) with mood scores were only observed in the baseline period, when serum androgen levels were below the normal range. This observation may indicate that it is possible that, once a minimally adequate serum T/DHT level is achieved by $\mathrm{T}$ replacement therapy, further increases in serum T/DHT levels do not further contribute to the improvement in mood variables. In a subsequent trial, Wang et al. [82] administered a transdermal $\mathrm{T}$ gel formulation to hypogonadal men (227 men aged 19 to 68 years) over a period of 180 days. 


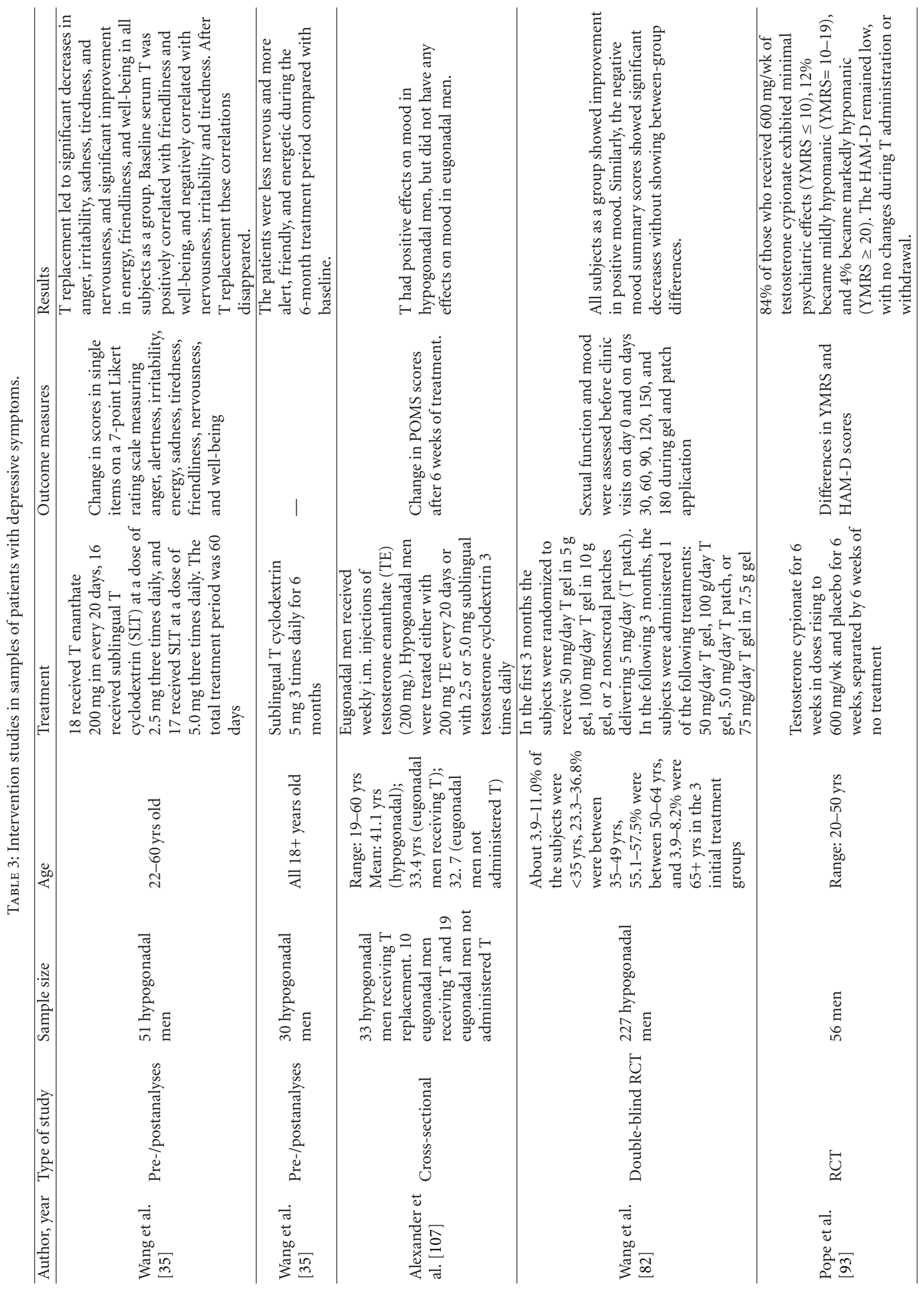




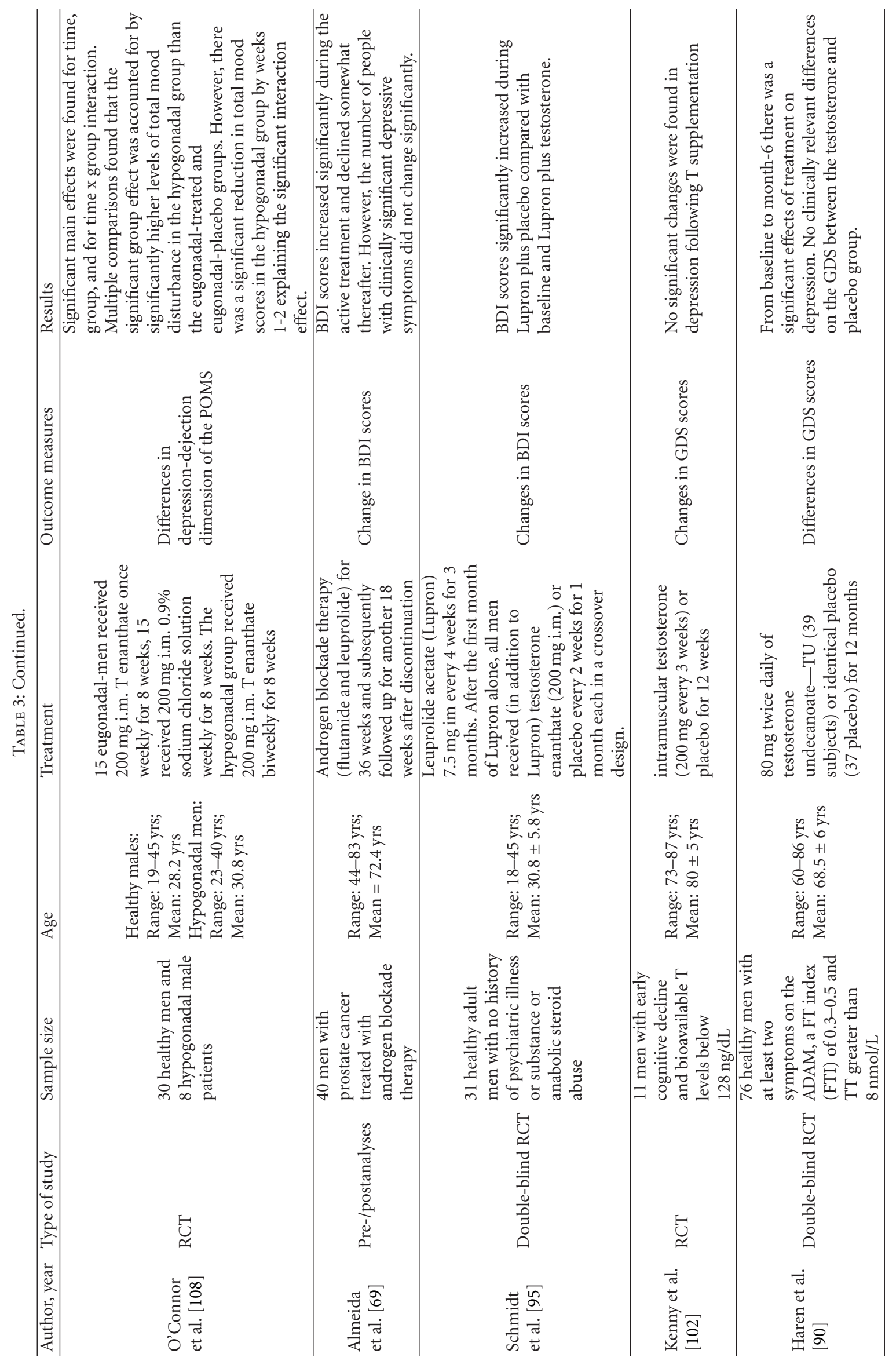




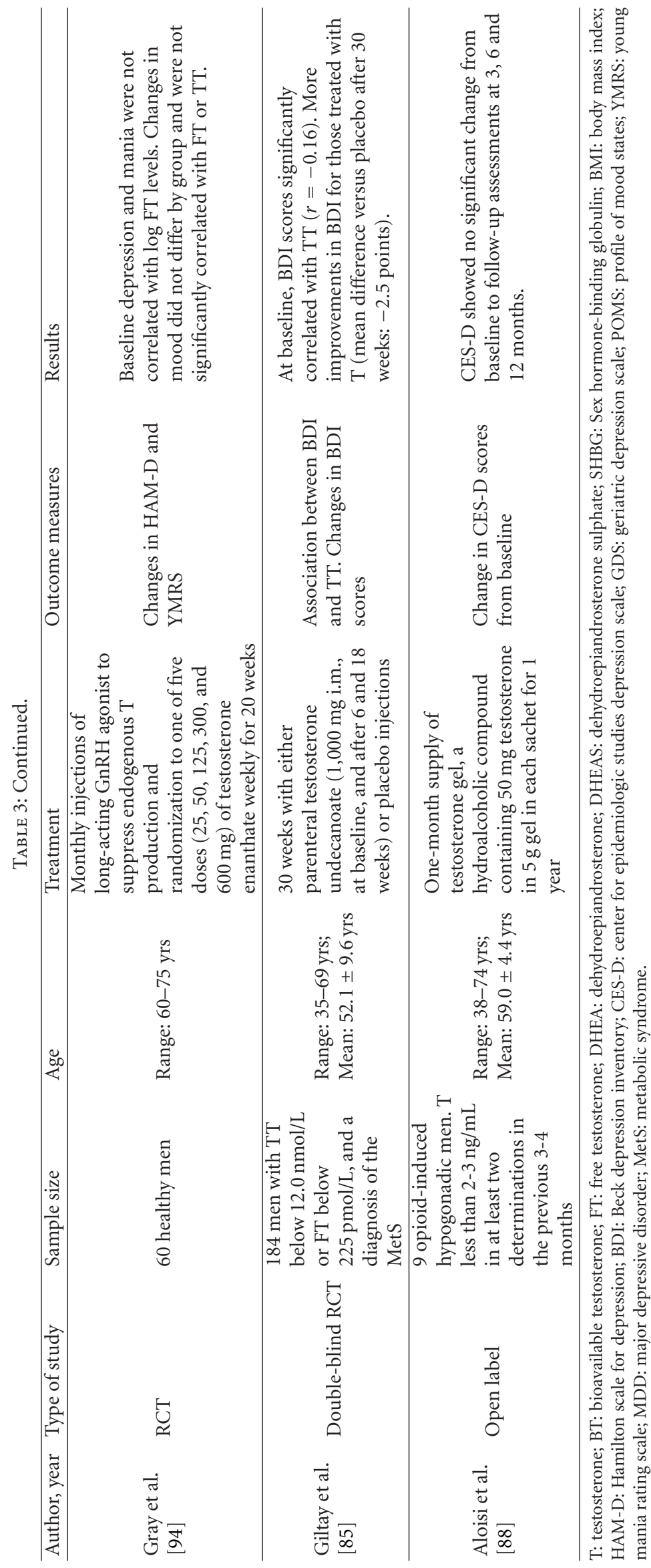




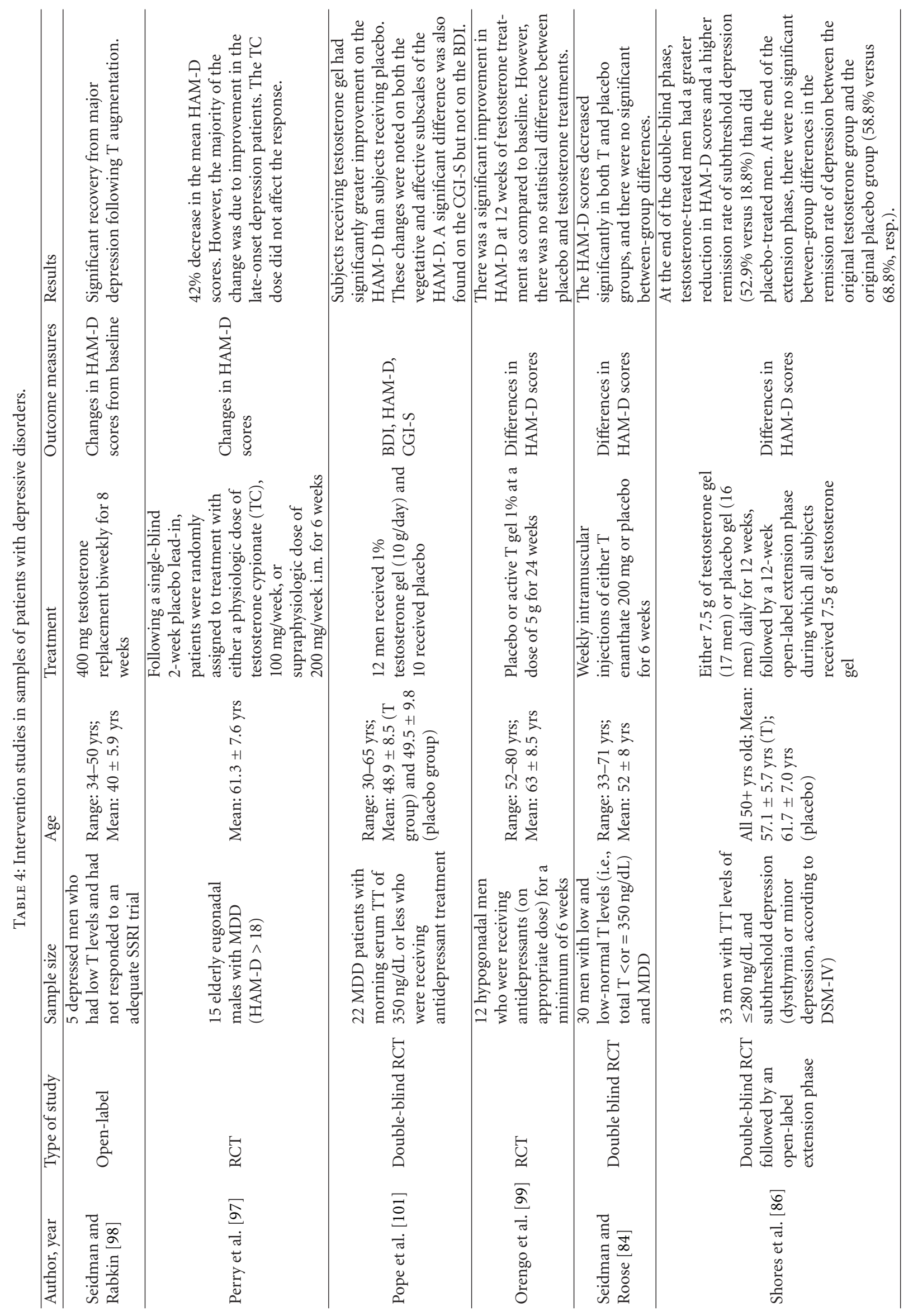




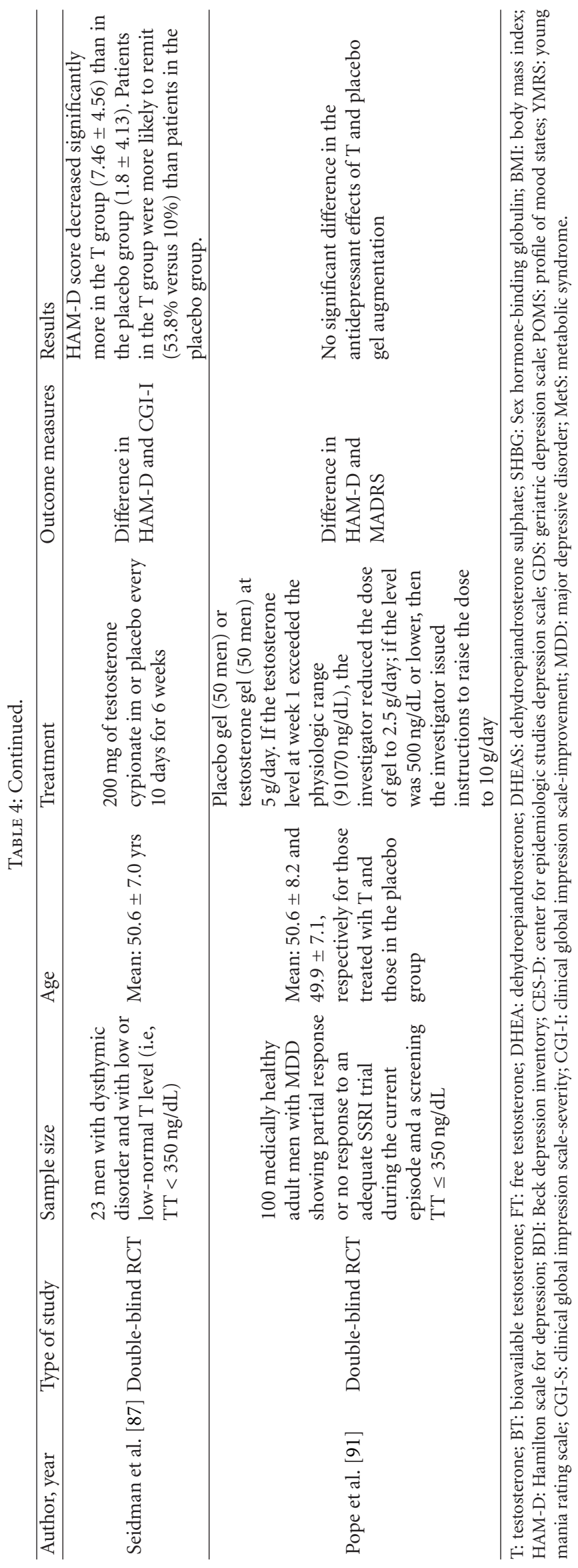


Mood improved and the improvement was maintained with continued treatment.

Recently, Shores et al. [86] examined the effect of testosterone treatment in older, hypogonadal men $(50+$ years old) with subthreshold depression in a double-blind randomized controlled trial. Participants received either $7.5 \mathrm{~g}$ of testosterone gel or placebo gel daily for 12 weeks, followed by a 12-week open-label extension phase during which all subjects received $7.5 \mathrm{~g}$ of testosterone gel. At the end of the double-blind phase, testosterone-treated men had a greater reduction in depression $(P<0.05)$ and a higher remission rate of subthreshold depression (52.9\% versus $18.8 \%, P<0.05)$ than did placebo-treated men. At the end of the open-label phase, the testosterone group had sustained improvement, while patients who had received placebo in the previous 12 weeks improved, and there were no differences between groups on the number of depressive symptoms reported.

Seidman et al. [87] conducted a six-week double-blind placebo-controlled clinical trial in 23 men with mid-life onset male dysthymic disorder and with low or low-normal testosterone level $(\mathrm{TT}<350 \mathrm{ng} / \mathrm{dL})$. After the intervention, the depression decreased significantly more in the testosterone group than in the placebo group $(P<0.01)$.

However, some studies have shown that, in the short and long term [88], T replacement is not superior to placebo in elderly men with low-normal gonadal status, or in men with the lowest BT levels [89-91].

Androgen treatment in eugonadal men has demonstrated subtle changes in sexual arousal, cognition, and mood [36], with a significant increase in manic and aggressive symptoms $[92,93]$. However, two studies failed to observe effects of T on mood in healthy men with induced hypogonadism who were given $\mathrm{T}[94,95]$.

To date, little evidence supports the use of androgen therapy in older depressed men [96]. In a study by Perry et al. [97], a subgroup of elderly depressed males (aged 70 and over) improved with $\mathrm{T}$ therapy. In a study of 15 elderly eugonadal males with major depressive disorder (MDD, according to the DSM-IV criteria), 5 with early onset MDD, and 10 with late onset MDD, treatment with $\mathrm{T}$ cypionate (100 mg/week or $200 \mathrm{mg} /$ week IM for 6 weeks) was efficacious only in some cases of late-onset depression.

Androgen administration in open and blind clinical trials to chronically depressed men or to hypogonadal men with depression refractory to selective serotonin reuptake inhibitors (SSRIs) improved depressive symptoms. Human and animal studies have demonstrated that $\mathrm{T}$ treatment may facilitate the antidepressant drug response [98-100]. $\mathrm{T}$ augmentation in men with major depression refractory to SSRIs treatment and low or borderline TT levels (200$350 \mathrm{ng} / \mathrm{dL}$ ) produced significant positive results in shortterm treatment (12 weeks) $[98,101]$, but doubts arose about longer-term treatment (20 weeks) [99].

At the present time, available data do not suggest the use of $\mathrm{T}$ in the treatment of depression in PADAM. Data on older men suffering from depression and PADAM are still few and inadequate [102], and the current clinical guidelines for men with low serum $\mathrm{T}$ concentration stress that $\mathrm{T}$ therapy for depression is irrelevant $[12,103,104]$.

Furthermore, T supplementation may be associated with some adverse effects, such as erythrocytosis, acne and oily skin, detection of subclinical prostate cancer, growth of metastatic prostate cancer, and reduced sperm production and fertility $[12,104]$. Other, uncommon, adverse events for which there is weak evidence of association with testosterone administration are gynecomastia, male pattern balding (familial), and induction or worsening of obstructive sleep apnea. Formulation-specific adverse effects include fluctuation in mood or libido, pain at injection site, excessive erythrocytosis (especially in older patients), and coughing episodes immediately after the intramuscular injection for intramuscular injections of testosterone enanthate, cypionate, or undecanoate, as well as frequent skin reactions at application site for transdermal patches, and potential risk for testosterone transfer to partner or others in close contact with the individual, and skin irritation for transdermal gel [12].

\section{Discussion}

As Western populations represent an aging society with continuing gains in life expectancy [4], hypogonadism in older men may have significant public health implications $[67,109,110]$. For example, over the last decade, this has led to a significant market growth in T therapies for men 40 years and older [4].

PADAM includes behavioral and depressive symptoms that vary greatly from individual to individual, being the result not only of biological and psychosocial changes, but also of personal ability to adapt to such changes. The efficacy of $\mathrm{T}$ therapy in the treatment of depression in elderly hypogonadal men is inconclusive. Research on $\mathrm{T}$ replacement therapy for depressive symptoms of PADAM reveals the great variability of the results.

Nonetheless, androgens supplementation may be a useful as adjunctive therapy in depressed hypogonadal men. Several study reported that antidepressants may be associated with sexual dysfunction in adult patients [111], and up to $20 \%$ of users may suffer from sexual dysfunction [112]. Sexual dysfunction may also be associated with discontinuation of antidepressants treatment [113]. T treatment may have beneficial effects on sexual functions [83, 89, 94, 103, 114-116]. Recently, Amiaz et al. [83] conducted a 6-week, double-blind, placebo-controlled clinical trial of testosterone gel versus placebo gel in men with MDD who were currently taking a serotonergic antidepressant and exhibited low or low-normal testosterone level. The results indicated that those taking testosterone improved in sexual functions as measured through the International Index of Erectile Function more than those in the placebo arm. Furthermore, the results indicated that the improvement in sexual functioning did not appear to be attributable to improvement in depression.

T treatment may be particularly useful to improve quality of life in elderly hypogonadal men, because its effect on muscular strength [117-119] and may be on cognitive functions $[57,120-122]$. 
However, due to adverse effects associated with T therapy, pretreatment screening for parameters related to potential risks of testosterone supplementation is essential. T supplementation is contraindicated in individuals with hematocrit of $52 \%$ and over $[123,124]$, prostatic carcinoma, an androgen sensitive-tumor, and in cases of mammary carcinoma in men $[12,103]$.

In conclusion, despite the causative nature of the relationship between low T levels and depression is uncertain, many hypogonadal men suffer from depression and vice versa. Supplementation with testosterone failed to show sound evidence of effectiveness in the treatment of depression. Nevertheless, T supplementation has proved to be effective on some domains significant for the quality of life of patients with PADAM. Those effects may partially mediate the effects on depressive symptomatology reported in some trials. Thus, the overall improvement in well-being and health, related to the quality of life in aging males with partial androgen deficiency, may have a positive impact on their mood.

\section{Conflict of Interests}

The authors declare that there is no conflict of interest associated with this manuscript.

\section{References}

[1] A. Nardozza Jr., S. Szelbracikowski Sdos, A. C. Nardi, and J. C. Almeida, "Age-related testosterone decline in a Brazilian cohort of healthy military men," International Brazilian Journal of Urology, vol. 37, pp. 591-597, 2011.

[2] A. B. Araujo, A. B. O’Donnell, D. J. Brambilla et al., "Prevalence and incidence of androgen deficiency in middle-aged and older men: estimates from the Massachusetts male aging study," Journal of Clinical Endocrinology and Metabolism, vol. 89, no. 12, pp. 5920-5926, 2004.

[3] G. Valenti, "The pathway of partial androgen deficiency of aging male," Journal of Endocrinological Investigation, vol. 28, no. 11, pp. 28-33, 2005.

[4] C. A. Allan and R. I. McLachlan, "Age-related changes in testosterone and the role of replacement therapy in older men," Clinical Endocrinology, vol. 60, no. 6, pp. 653-670, 2004.

[5] C. C. Liu, W. J. Wu, Y. C. Lee et al., "The prevalence of and risk factors for androgen deficiency in aging Taiwanese men," Journal of Sexual Medicine, vol. 6, no. 4, pp. 936-946, 2009.

[6] J. E. Lackner, E. Rucklinger, G. Schatzl, G. Lunglmayr, and C. W. Kratzik, "Are there symptom-specific testosterone thresholds in aging men?" British Journal of Urology International, vol. 108, pp. 1310-1315, 2011.

[7] F. C. W. Wu, A. Tajar, J. M. Beynon et al., "Identification of late-onset hypogonadism in middle-aged and elderly men," New England Journal of Medicine, vol. 363, no. 2, pp. 123$135,2010$.

[8] E. Nieschlag, R. Swerdloff, H. M. Behre et al., "Investigation, treatment, and monitoring of late-onset hypogonadism in males: ISA, ISSAM, and EAU recommendations," Journal of Andrology, vol. 27, no. 2, pp. 135-137, 2006.

[9] C. Wang, E. Nieschlag, R. Swerdloff et al., "Investigation, treatment and monitoring of late-onset hypogonadism in males: ISA, ISSAM, EAU, EAA and ASA recommendations," European Journal of Endocrinology, vol. 159, no. 5, pp. 507514, 2008.

[10] A. Vermeulen, "Hormonal cut-offs of partial androgen deficiency: a survey of androgen assays," Journal of Endocrinological Investigation, vol. 28, no. 3, pp. 28-31, 2005.

[11] W. Rosner, R. J. Auchus, R. Azziz, P. M. Sluss, and H. Raff, "Position statement: utility, limitations, and pitfalls in measuring testosterone: an endocrine society position statement," Journal of Clinical Endocrinology and Metabolism, vol. 92, no. 2, pp. 405-413, 2007.

[12] S. Bhasin and A. M. Matsumoto, "Patient information page from The Hormone Foundation. Patient guide to testosterone therapy in adult men with androgen deficiency syndromes," The Journal of Clinical Endocrinology and Metabolism, vol. 95, no. 6, pp. 2-3085, 2010.

[13] S. Bhasin, A. Zhang, A. Coviello et al., "The impact of assay quality and reference ranges on clinical decision making in the diagnosis of androgen disorders," Steroids, vol. 73, no. 13, pp. 1311-1317, 2008.

[14] S. M. Harman, E. J. Metter, J. D. Tobin, J. Pearson, and M. R. Blackman, "Longitudinal effects of aging on serum total and free testosterone levels in healthy men," Journal of Clinical Endocrinology and Metabolism, vol. 86, no. 2, pp. 724-731, 2001.

[15] S. A. Hall, G. R. Esche, A. B. Araujo et al., "Correlates of low testosterone and symptomatic androgen deficiency in a population-based sample," Journal of Clinical Endocrinology and Metabolism, vol. 93, no. 10, pp. 3870-3877, 2008.

[16] A. W. Meikle, D. T. Bishop, J. D. Stringham, and D. W. West, "Quantitating genetic and nongenetic factors that determine plasma sex steroid variation in normal male twins," Metabolism, vol. 35, no. 12, pp. 1090-1095, 1986.

[17] H. E. Turner and J. A. H. Wass, "Gonadal function in men with chronic illness," Clinical Endocrinology, vol. 47, no. 4, pp. 379-403, 1997.

[18] V. Rochira, L. Zirilli, G. Orlando, D. Santi, G. Brigante, and C. Diazzi, "Premature decline of serum total testosterone in HIV-infected men in the HAART-Era," PLoS ONE, vol. 6, Article ID e28512, 2011.

[19] M. M. Miner, M. Khera, R. K. Bhattacharya, G. Blick, and H. Kushner, "Baseline data from the TRiUS registry: symptoms and comorbidities of testosterone deficiency," Postgraduate Medicine, vol. 123, no. 3, pp. 17-27, 2011.

[20] M. R. MacAdams, R. H. White, and B. E. Chipps, "Reduction of serum testosterone levels during chronic glucocorticoid therapy," Annals of Internal Medicine, vol. 104, no. 5, pp. 648651, 1986.

[21] A. Vermeulen, J. M. Kaufman, and V. A. Giagulli, "Influence of some biological indexes on sex hormone-binding globulin and androgen levels in aging or obese males," Journal of Clinical Endocrinology and Metabolism, vol. 81, no. 5, pp. 18211826, 1996.

[22] S. G. Anderson, A. Heald, N. Younger, S. Bujawansa, R. P. Narayanan, A. McCulloch et al., "Screening for hypogonadism in diabetes 2008/9: results from the Cheshire Primary Care cohort," Primary Care Diabetes, vol. 6, no. 2, pp. 143148, 2011.

[23] T. G. Travison, A. B. Araujo, V. Kupelian, A. B. O’Donnell, and J. B. McKinlay, "The relative contributions of aging, health, and lifestyle factors to serum testosterone decline in men," Journal of Clinical Endocrinology and Metabolism, vol. 92, no. 2, pp. 549-555, 2007. 
[24] P. B. Gray, C. F. Yang, and H. G. Pope, "Fathers have lower salivary testosterone levels than unmarried men and married non-fathers in Beijing, China," Proceedings of the Biological Sciences, vol. 273, no. 1584, pp. 333-339, 2006.

[25] A. B. Araujo, G. R. Esche, V. Kupelian et al., "Prevalence of symptomatic androgen deficiency in men," Journal of Clinical Endocrinology and Metabolism, vol. 92, no. 11, pp. 42414247, 2007.

[26] E. Nieschlag, R. Swerdloff, H. M. Behre et al., "Investigation, treatment and monitoring of late-onset hypogonadism in males: ISA, ISSAM, and EAU recommendations," International Journal of Andrology, vol. 28, no. 3, pp. 125-127, 2005.

[27] J. B. Shelton and J. Rajfer, "Androgen deficiency in aging and metabolically challenged men," Urologic Clinics of North America, vol. 39, pp. 63-75, 2012.

[28] A. S. Burris, S. M. Banks, C. S. Carter, J. M. Davidson, and R. J. Sherins, "A long-term, prospective study of the physiologic and behavioral effects of hormone replacement in untreated hypogonadal men," Journal of Andrology, vol. 13, no. 4, pp. 297-304, 1992.

[29] A. Hamidi Madani, A. Heidarzadeh, N. Akbari Parsa, F. Khosravi Darestani, and Z. Hamidi Madani, "A survey on relative frequency of metabolic syndrome and testosterone deficiency in men with erectile dysfunction," International Urology and Nephrology, vol. 44, no. 3, pp. 667-672, 2012.

[30] R. J. Urban, Y. H. Bodenburg, C. Gilkison et al., "Testosterone administration to elderly men increases skeletal muscle strength and protein synthesis," American Journal of Physiology, vol. 269, no. 5, pp. E820-E826, 1995.

[31] J. S. Tenover, "Androgen administration to aging men," Endocrinology and Metabolism Clinics of North America, vol. 23, no. 4, pp. 877-892, 1994.

[32] N. Itoh and T. Tsukamoto, "Clinical aspects of partial androgen deficiency of aging male (PADAM)," Clinical Calcium, vol. 13, pp. 1432-1437, 2003.

[33] E. O. Abu, A. Horner, V. Kusec, J. T. Triffitt, and J. E. Compston, "The localization of androgen receptors in human bone," Journal of Clinical Endocrinology and Metabolism, vol. 82, no. 10, pp. 3493-3497, 1997.

[34] N. A. Hibberts, A. E. Howell, and V. A. Randall, "Balding hair follicle dermal papilla cells contain higher levels of androgen receptors than those from non-balding scalp," Journal of Endocrinology, vol. 156, no. 1, pp. 59-65, 1998.

[35] C. Wang, G. Alexander, N. Berman et al., "Testosterone replacement therapy improves mood in hypogonadal mena clinical research center study," Journal of Clinical Endocrinology and Metabolism, vol. 81, no. 10, pp. 3578-3583, 1996.

[36] D. R. Rubinow and P. J. Schmidt, "Androgens, brain, and behavior," American Journal of Psychiatry, vol. 153, no. 8, pp. 974-984, 1996.

[37] A. A. Werner, "The male climacteric," Journal of the American Medical Association, vol. 132, pp. 188-194, 1946.

[38] R. B. Greenblatt, C. Nezhat, R. A. Roesel, and P. K. Natrajan, "Update on the male and female climacteric," Journal of the American Geriatrics Society, vol. 27, no. 11, pp. 481-490, 1979.

[39] Y. Sato, S. Kato, S. Ohnishi et al., "Analysis of clinical manifestations and endocrinological aspects of patients having PADAM-like symptoms," Japanese Journal of Urology, vol. 95, no. 1, pp. 8-16, 2004.

[40] G. M. Alexander, R. S. Swerdloff, C. Wang et al., "Androgenbehavior correlations in hypogonadal men and eugonadal men. II. Cognitive abilities," Hormones and Behavior, vol. 33, no. 2, pp. 85-94, 1998.
[41] K. Walker, “The male climacteric," Postgraduate Medical Journal, vol. 14, pp. 120-123, 1938.

[42] W. W. Hochreiter, D. K. Ackermann, and H. P. Brütsch, "Andropause," Therapeutische Umschau, vol. 62, no. 12, pp. 821-826, 2005.

[43] A. C. E. Spetz, L. Palmefors, R. S. P. Skobe et al., "Testosterone correlated to symptoms of partial androgen deficiency in aging men (PADAM) in an elderly Swedish population," Menopause, vol. 14, no. 6, pp. 999-1005, 2007.

[44] R. S. McIntyre, D. Mancini, B. S. Eisfeld et al., "Calculated bioavailable testosterone levels and depression in middleaged men," Psychoneuroendocrinology, vol. 31, no. 9, pp. 1029-1035, 2006.

[45] American Psychiatric Association, Diagnostic and Statistical Manual of Mental Disorders, American Psychiatric Association, Washington, DC, USA, 4th edition, 2000.

[46] L. Di, P. Sgrò, V. Fierro et al., "Prevalence of undiagnosed testosterone deficiency in aging athletes: does exercise training influence the symptoms of male hypogonadism?" Journal of Sexual Medicine, vol. 7, no. 7, pp. 2591-2601, 2010.

[47] J. Hintikka, L. Niskanen, H. Koivumaa-Honkanen et al., "Hypogonadism, decreased sexual desire, and long-term depression in middle-aged men," Journal of Sexual Medicine, vol. 6, no. 7, pp. 2049-2057, 2009.

[48] M. Markianos, J. Tripodianakis, C. Istikoglou et al., "Suicide attempt by jumping: a study of gonadal axis hormones in male suicide attempters versus men who fell by accident," Psychiatry Research, vol. 170, no. 1, pp. 82-85, 2009.

[49] E. A. Jankowska, A. Drohomirecka, B. Ponikowska et al., "Deficiencies in circulating testosterone and dehydroepiandrosterone sulphate, and depression in men with systolic chronic heart failure," European Journal of Heart Failure, vol. 12, no. 9, pp. 966-973, 2010.

[50] S. Fukai, M. Akishita, S. Yamada et al., "Association of plasma sex hormone levels with functional decline in elderly men and women," Geriatrics and Gerontology International, vol. 9, no. 3, pp. 282-289, 2009.

[51] A. Ponholzer, S. Madersbacher, M. Rauchenwald, S. Jungwirth, P. Fischer, and K. H. Tragl, "Serum androgen levels and their association to depression and Alzheimer dementia in a cohort of 75-year-old men over 5 years: results of the VITA study," International Journal of Impotence Research, vol. 21, no. 3, pp. 187-191, 2009.

[52] A. A. Makhlouf, M. A. Mohamed, A. D. Seftel, and C. Neiderberger, "Hypogonadism is associated with overt depression symptoms in men with erectile dysfunction," International Journal of Impotence Research, vol. 20, no. 2, pp. 157-161, 2008.

[53] L. F. J. Morsink, N. Vogelzangs, B. J. Nicklas et al., "Associations between sex steroid hormone levels and depressive symptoms in elderly men and women: results from the Health ABC study," Psychoneuroendocrinology, vol. 32, no. 810, pp. 874-883, 2007.

[54] C. W. Kratzik, G. Schatzl, J. E. Lackner et al., "Mood changes, body mass index and bioavailable testosterone in healthy men: results of the Androx Vienna Municipality Study," BJU International, vol. 100, no. 3, pp. 614-618, 2007.

[55] F. Strasser, J. L. Palmer, L. R. Schover et al., "The impact of hypogonadism and autonomic dysfunction on fatigue, emotional function, and sexual desire in male with advanced center: a pilot study," Cancer, vol. 107, no. 12, pp. 2949-2957, 2006.

[56] L. H. Berglund, H. S. Prytz, A. Perski, and J. Svartberg, "Testosterone levels and psychological health status in men 
from a general population: the Tromsø study," Aging Male, vol. 14, no. 1, pp. 37-41, 2011.

[57] S. D. Moffat, A. B. Zonderman, E. Jeffrey Metter, M. R. Blackman, S. Mitchell Harman, and S. M. Resnick, "Longitudinal assessment of serum free testosterone concentration predicts memory performance and cognitive status in elderly men," Journal of Clinical Endocrinology and Metabolism, vol. 87, no. 11, pp. 5001-5007, 2002.

[58] A. Mazur, "Biosocial models of deviant behavior among male army veterans," Biological Psychology, vol. 41, no. 3, pp. 271293, 1995.

[59] J. M. Dabbs Jr., C. H. Hopper, and G. J. Jurkovic, “Testosterone and personality among college students and military veterans," Personality and Individual Differences, vol. 11, no. 12, pp. 1263-1269, 1990.

[60] U. Schweiger, M. Deuschle, B. Weber et al., "Testosterone, gonadotropin, and cortisol secretion in male patients with major depression," Psychosomatic Medicine, vol. 61, no. 3, pp. 292-296, 1999.

[61] A. Steiger, U. Von Bardeleben, K. Wiedemann, and F. Holsboer, "Sleep EEG and nocturnal secretion of testosterone and cortisol in patients with major endogenous depression during acute phase and after remission," Journal of Psychiatric Research, vol. 25, no. 4, pp. 169-177, 1991.

[62] S. N. Seidman, A. B. Araujo, S. P. Roose et al., "Low testosterone levels in elderly men with dysthymic disorder," American Journal of Psychiatry, vol. 159, no. 3, pp. 456-459, 2002.

[63] S. Halabi, E. G. Collins, N. Thorevska, M. J. Tobin, and F. Laghi, "Relationship between depressive symptoms and hypogonadism in men with COPD," COPD, vol. 8, pp. 346353, 2011.

[64] E. Barrett-Connor, D. G. Von Mühlen, and D. KritzSilverstein, "Bioavailable testosterone and depressed mood in older men: the Rancho Bernardo study," Journal of Clinical Endocrinology and Metabolism, vol. 84, no. 2, pp. 573-577, 1999.

[65] A. T. Beck, R. A. Steer, R. Ball, and W. F. Ranieri, "Comparison of Beck depression inventories -IA and -II in psychiatric outpatients," Journal of Personality Assessment, vol. 67, no. 3, pp. 588-597, 1996.

[66] A. M. Lee, L. W. Chu, C. S. Y. Chong et al., "Relationship between symptoms of androgen deficiency and psychological factors and quality of life among Chinese men," International Journal of Andrology, vol. 33, no. 5, pp. 755-763, 2010.

[67] M. M. Shores, K. L. Sloan, A. M. Matsumoto, V. M. Moceri, B. Felker, and D. R. Kivlahan, "Increased incidence of diagnosed depressive illness in hypogonadal older men," Archives of General Psychiatry, vol. 61, no. 2, pp. 162-167, 2004.

[68] S. N. Seidman and B. T. Walsh, "Testosterone and depression in aging men," American Journal of Geriatric Psychiatry, vol. 7, no. 1, pp. 18-33, 1999.

[69] O. P. Almeida, A. Waterreus, N. Spry, L. Flicker, and R. N. Martins, "One year follow-up study of the association between chemical castration, sex hormones, beta-amyloid, memory and depression in men," Psychoneuroendocrinology, vol. 29, no. 8, pp. 1071-1081, 2004.

[70] A. B. Araujo, R. Durante, H. A. Feldman, I. Goldstein, and J. B. Mckinlay, "The relationship between depressive symptoms and male erectile dysfunction: cross-sectional results from the Massachusetts male aging study," Psychosomatic Medicine, vol. 60, no. 4, pp. 458-465, 1998.

[71] A. Booth, D. R. Johnson, and D. A. Granger, "Testosterone and men's depression: the role of social behavior," Journal of Health and Social Behavior, vol. 40, no. 2, pp. 130-140, 1999.
[72] S. N. Seidman, A. B. Araujo, S. P. Roose, and J. B. McKinlay, "Testosterone level, androgen receptor polymorphism, and depressive symptoms in middle-aged men," Biological Psychiatry, vol. 50, no. 5, pp. 371-376, 2001.

[73] E. Nieschlag and H. Behre, Testosterone: Action, Deficiency, Substitution, Cambridge University Press, 2004.

[74] M. Zitzmann and E. Nieschlag, "The CAG repeat polymorphism within the androgen receptor gene and maleness," International Journal of Andrology, vol. 26, no. 2, pp. 76-83, 2003.

[75] J. S. Janowsky, “Thinking with your gonads: testosterone and cognition," Trends in Cognitive Sciences, vol. 10, no. 2, pp. 7782, 2006.

[76] M. Robichaud and G. Debonnel, "Oestrogen and testosterone modulate the firing activity of dorsal raphe nucleus serotonergic neurones in both male and female rats," Journal of Neuroendocrinology, vol. 17, no. 3, pp. 179-185, 2005.

[77] B. E. H. Sumner and G. Fink, "Testosterone as well as estrogen increases serotonin ${ }_{2 A}$ receptor mRNA and binding site densities in the male rat brain," Molecular Brain Research, vol. 59, no. 2, pp. 205-214, 1998.

[78] G. Fink, B. Sumner, R. Rosie, H. Wilson, and J. McQueen, "Androgen actions on central serotonin neurotransmission: relevance for mood, mental state and memory," Behavioural Brain Research, vol. 105, no. 1, pp. 53-68, 1999.

[79] C. E. Brown-Séquard, "Effects in man of subcutaneous injections of freshly prepared liquid from guinea pig and dog testes," Comptes Rendus des Séances et Mémoires de la Société de Biologie, vol. 9, pp. 415-149, 1889.

[80] C. E. Brown-Séquard, "On a new therapeutic method consisting in the use of organic liquids extracted from glands and other organs," The Lancet, vol. 134, no. 3438, pp. 105-107, 1889.

[81] C. E. Brown-Séquard, "On a new therapeutic method consisting in the use of organic liquids extracted from glands and other organs," British Medical Journal, vol. 1, pp. 1212-1214, 1893.

[82] C. Wang, R. S. Swerdloff, A. Iranmanesh et al., "Transdermal testosterone gel improves sexual function, mood, muscle strength, and body composition parameters in hypogonadal men," Journal of Clinical Endocrinology and Metabolism, vol. 85, pp. 2839-2853, 2000.

[83] R. Amiaz, H. G. Pope, T. Mahne et al., “Testosterone gel replacement improves sexual function in depressed men taking serotonergic antidepressants: a randomized, placebocontrolled clinical trial," Journal of Sex and Marital Therapy, vol. 37, no. 4, pp. 243-254, 2011.

[84] S. N. Seidman and S. P. Roose, "The sexual effects of testosterone replacement in depressed men: randomized, placebocontrolled clinical trial," Journal of Sex and Marital Therapy, vol. 32, no. 3, pp. 267-273, 2006.

[85] E. J. Giltay, Y. A. Tishova, G. J. Mskhalaya, L. J. Gooren, F. Saad, and S. Y. Kalinchenko, "Effects of testosterone supplementation on depressive symptoms and sexual dysfunction in hypogonadal men with the metabolic syndrome," Journal of Sexual Medicine, vol. 7, no. 7, pp. 2572-2582, 2010.

[86] M. M. Shores, D. R. Kivlahan, T. I. Sadak, E. J. Li, and A. M. Matsumoto, "A randomized, double-blind, placebocontrolled study of testosterone treatment in hypogonadal older men with subthreshold depression (dysthymia or minor depression)," Journal of Clinical Psychiatry, vol. 70, no. 7, pp. 1009-1016, 2009.

[87] S. N. Seidman, G. Orr, G. Raviv et al., "Effects of testosterone replacement in middle-aged men with dysthymia: a 
randomized, placebo-controlled clinical trial," Journal of Clinical Psychopharmacology, vol. 29, no. 3, pp. 216-221, 2009.

[88] A. M. Aloisi, I. Ceccarelli, M. Carlucci et al., "Hormone replacement therapy in morphine-induced hypogonadic male chronic pain patients," Reproductive Biology and Endocrinology, vol. 9, article 26, 2011.

[89] M. Haren, I. Chapman, P. Coates, J. Morley, and G. Wittert, "Effect of 12 month oral testosterone on testosterone deficiency symptoms in symptomatic elderly males with lownormal gonadal status," Age and Ageing, vol. 34, no. 2, pp. 125-130, 2005.

[90] M. T. Haren, G. A. Wittert, I. M. Chapman, P. Coates, and J. E. Morley, "Effect of oral testosterone undecanoate on visuospatial cognition, mood and quality of life in elderly men with low-normal gonadal status," Maturitas, vol. 50, no. 2, pp. 124-133, 2005.

[91] H. G. Pope Jr., R. Amiaz, B. P. Brennan et al., "Parallelgroup placebo-controlled trial of testosterone gel in men with major depressive disorder displaying an incomplete response to standard antidepressant treatment," Journal of Clinical Psychopharmacology, vol. 30, no. 2, pp. 126-134, 2010.

[92] R. C. Daly, T. P. Su, P. J. Schmidt, M. Pagliaro, D. Pickar, and D. R. Rubinow, "Neuroendocrine and behavioral effects of high-dose anabolic steroid administration in male normal volunteers," Psychoneuroendocrinology, vol. 28, no. 3, pp. 317-331, 2003.

[93] H. G. Pope Jr., E. M. Kouri, and J. I. Hudson, "Effects of supraphysiologic doses of testosterone on mood and aggression in normal men: a randomized controlled trial," Archives of General Psychiatry, vol. 57, no. 2, pp. 133-140, 2000.

[94] P. B. Gray, A. B. Singh, L. J. Woodhouse et al., "Dosedependent effects of testosterone on sexual function, mood, and visuospatial cognition in older men," Journal of Clinical Endocrinology and Metabolism, vol. 90, no. 7, pp. 3838-3846, 2005.

[95] P. J. Schmidt, K. L. Berlin, M. A. Danaceau et al., "The effects of pharmacologically induced hypogonadism on mood in healthy men," Archives of General Psychiatry, vol. 61, no. 10, pp. 997-1004, 2004.

[96] N. T. Shamlian and M. G. Cole, "Androgen treatment of depressive symptoms in older men: a systematic review of feasibility and effectiveness," Canadian Journal of Psychiatry, vol. 51, no. 5, pp. 295-299, 2006.

[97] P. J. Perry, W. R. Yates, R. D. Williams et al., "Testosterone therapy in late-life major depression in males," Journal of Clinical Psychiatry, vol. 63, no. 12, pp. 1096-1101, 2002.

[98] S. N. Seidman and J. G. Rabkin, “Testosterone replacement therapy for hypogonadal men with SSRI- refractory depression," Journal of Affective Disorders, vol. 48, no. 2-3, pp. 157$161,1998$.

[99] C. A. Orengo, L. Fullerton, and M. E. Kunik, "Safety and efficacy of testosterone gel $1 \%$ augmentation in depressed men with partial response to antidepressant therapy," Journal of Geriatric Psychiatry and Neurology, vol. 18, no. 1, pp. 2024, 2005.

[100] L. Martínez-Mota and A. Fernández-Guasti, “Testosteronedependent antidepressant-like effect of noradrenergic but not of serotonergic drugs," Pharmacology Biochemistry and Behavior, vol. 78, no. 4, pp. 711-718, 2004.

[101] H. G. Pope Jr., G. H. Cohane, G. Kanayama, A. J. Siegel, and J. I. Hudson, "Testosterone gel supplementation for men with refractory depression: a randomized, placebo-controlled trial," American Journal of Psychiatry, vol. 160, no. 1, pp. 105$111,2003$.

[102] A. M. Kenny, G. Fabregas, C. Song, B. Biskup, and S. Bellantonio, "Effects of testosterone on behavior, depression, and cognitive function in older men with mild cognitive loss," Journals of Gerontology, vol. 59, no. 1, pp. 75-78, 2004.

[103] S. Bhasin, G. R. Cunningham, F. J. Hayes et al., "Testosterone therapy in adult men with androgen deficiency syndromes: an endocrine society clinical practice guideline," Journal of Clinical Endocrinology and Metabolism, vol. 91, no. 6, pp. 1995-2010, 2006.

[104] "Testosterone replacement therapy for male aging: ASA position statement," Journal of Andrology, vol. 27, pp. 133-134, 2006.

[105] G. G. T’Sjoen, S. De Vos, S. Goemaere et al., "Sex steroid level, androgen receptor polymorphism, and depressive symptoms in healthy elderly men," Journal of the American Geriatrics Society, vol. 53, no. 4, pp. 636-642, 2005.

[106] S. Y. Wong, J. C. Leung, T. Kwok, C. Ohlsson, L. Vandenput, P. C. Leung et al., "Low DHEAS levels are associated with depressive symptoms in elderly Chinese men: results from a large study," Asian Journal of Andrology, vol. 13, pp. 898-902, 2011.

[107] G. M. Alexander, R. S. Swerdloff, C. Wang et al., "Androgenbehavior correlations in hypogonadal men and eugonadal men: I. Mood and response to auditory sexual stimuli," Hormones and Behavior, vol. 31, no. 2, pp. 110-119, 1997.

[108] D. B. O'Connor, J. Archer, W. M. Hair, and F. C. W. Wu, "Exogenous testosterone, aggression, and mood in eugonadal and hypogonadal men," Physiology and Behavior, vol. 75, no. 4, pp. 557-566, 2002.

[109] A. M. Matsumoto, "Andropause: clinical implications of the decline in serum testosterone levels with aging in men," Journals of Gerontology, vol. 57, no. 2, pp. M76-M99, 2002.

[110] R. L. Ferrini and E. Barrett-Connor, "Sex hormones and age: a cross-sectional study of testosterone and estradiol and their bioavailable fractions in community-dwelling men," American Journal of Epidemiology, vol. 147, no. 8, pp. 750754, 1998.

[111] H. D. Anderson, W. D. Pace, A. M. Libby, D. R. West, and R. J. Valuck, "Rates of 5 common antidepressant side effects among new adult and adolescent cases of depression: a retrospective US claims study," Clinical Therapeutics, vol. 34, no. 1, pp. 113-123, 2012.

[112] M. A. Whooley and G. E. Simon, "Managing depression in medical outpatients," New England Journal of Medicine, vol. 343, no. 26 I, pp. 1942-1950, 2000.

[113] K. Kroenke, S. L. West, R. Swindle et al., "Similar effectiveness of paroxetine, fluoxetine, and sertraline in primary care: a randomized trial," Journal of the American Medical Association, vol. 286, no. 23, pp. 2947-2955, 2001.

[114] A. D. Seftel, R. J. Mack, A. R. Secrest, and T. M. Smith, "Restorative increases in serum testosterone levels are significantly correlated to improvements in sexual functioning," Journal of Andrology, vol. 25, no. 6, pp. 963-972, 2004.

[115] X. H. Zhang, A. Morelli, M. Luconi et al., "Testosterone regulates PDE5 expression and in vivo responsiveness to tadalafil in rat corpus cavernosum," European Urology, vol. 47, no. 3, pp. 409-416, 2005.

[116] A. Morelli, S. Filippi, R. Mancina et al., "Androgens regulate phosphodiesterase type 5 expression and functional activity in corpora cavernosa," Endocrinology, vol. 145, pp. 22532263, 2004. 
[117] I. Sinha-Hikim, M. Cornford, H. Gaytan, M. L. Lee, and S. Bhasin, "Effects of testosterone supplementation on skeletal muscle fiber hypertrophy and satellite cells in communitydwelling older men," Journal of Clinical Endocrinology and Metabolism, vol. 91, no. 8, pp. 3024-3033, 2006.

[118] S. Bhasin, L. Woodhouse, R. Casaburi et al., "Older men are as responsive as young men to the anabolic effects of graded doses of testosterone on the skeletal muscle," Journal of Clinical Endocrinology and Metabolism, vol. 90, no. 2, pp. 678-688, 2005.

[119] S. T. Page, J. K. Amory, F. D. Bowman et al., "Exogenous testosterone $(\mathrm{T})$ alone or with finasteride increases physical performance, grip strength, and lean body mass in older men with low serum T," Journal of Clinical Endocrinology and Metabolism, vol. 90, no. 3, pp. 1502-1510, 2005.

[120] P. P. Thilers, S. W. S. MacDonald, and A. Herlitz, "The association between endogenous free testosterone and cognitive performance: a population-based study in 35 to 90 yearoldmen and women," Psychoneuroendocrinology, vol. 31, no. 5, pp. 565-576, 2006.

[121] M. M. Cherrier, A. M. Matsumoto, J. K. Amory et al., “The role of aromatization in testosterone supplementation: effects on cognition in older men," Neurology, vol. 64, no. 2, pp. 290 296, 2005.

[122] A. M. Kenny, S. Bellantonio, C. A. Gruman, R. D. Acosta, and K. M. Prestwood, "Effects of transdermal testosterone on cognitive function and health perception in older men with low bioavailable testosterone levels," Journals of Gerontology, vol. 57, no. 5, pp. M321-M325, 2002.

[123] A. Vermeulen, “Andropause," Maturitas, vol. 34, no. 1, pp. 5$15,2000$.

[124] J. K. Amory, N. B. Watts, K. A. Easley et al., "Exogenous testosterone or testosterone with finasteride increases bone mineral density in older men with low serum testosterone," Journal of Clinical Endocrinology and Metabolism, vol. 89, no. 2, pp. 503-510, 2004. 


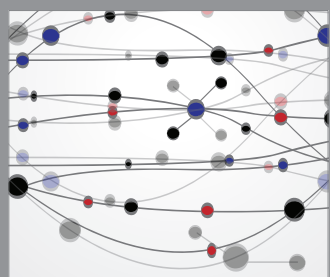

The Scientific World Journal
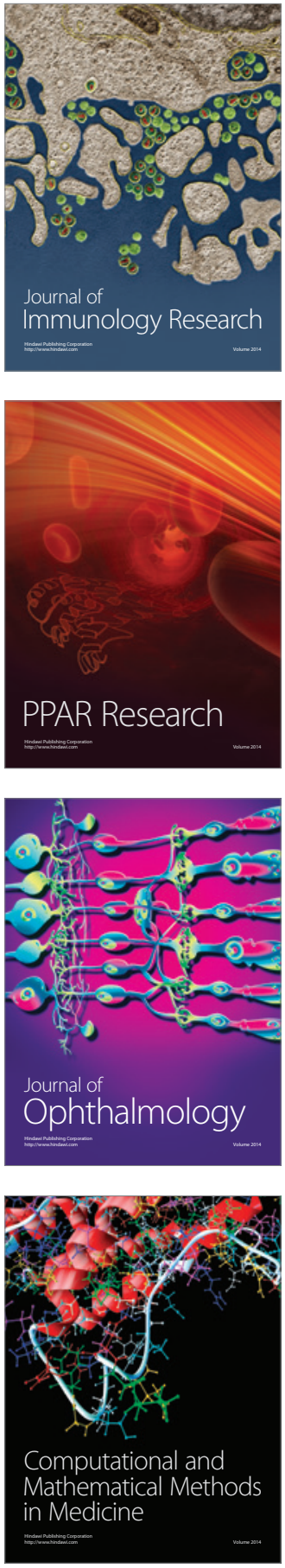

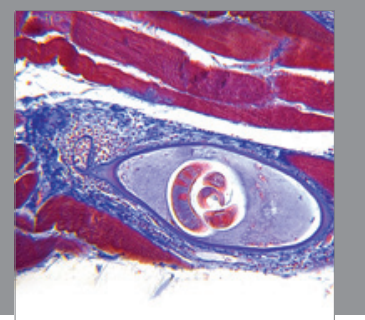

Gastroenterology

Research and Practice
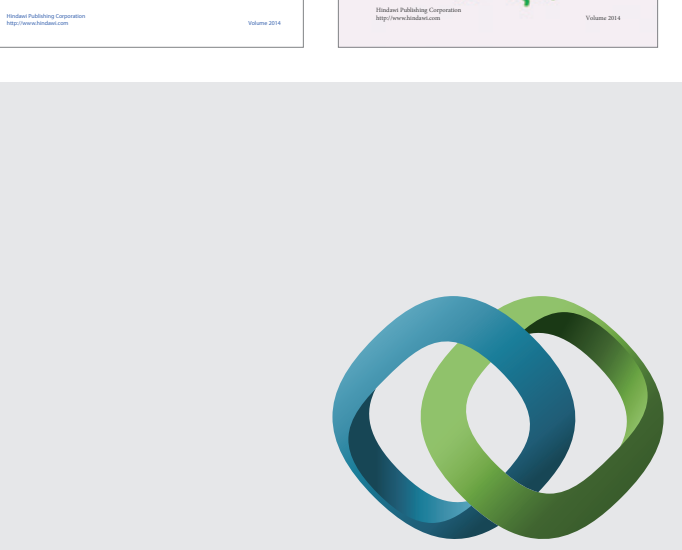

\section{Hindawi}

Submit your manuscripts at

http://www.hindawi.com
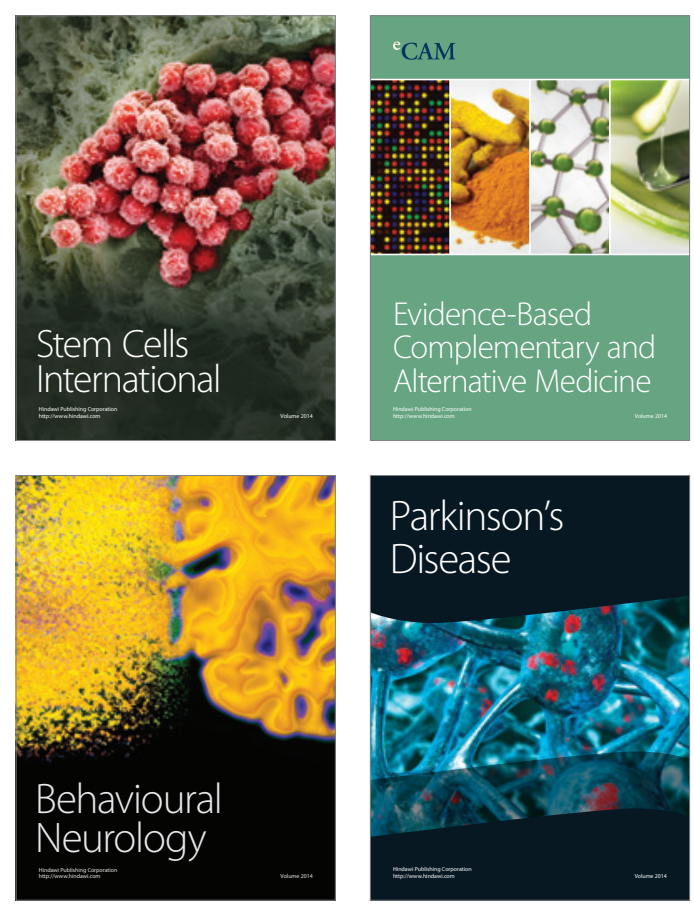

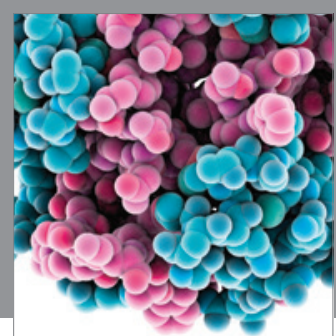

Journal of
Diabetes Research

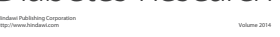

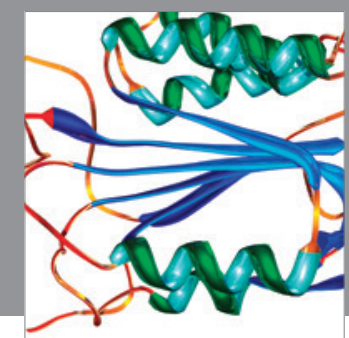

Disease Markers
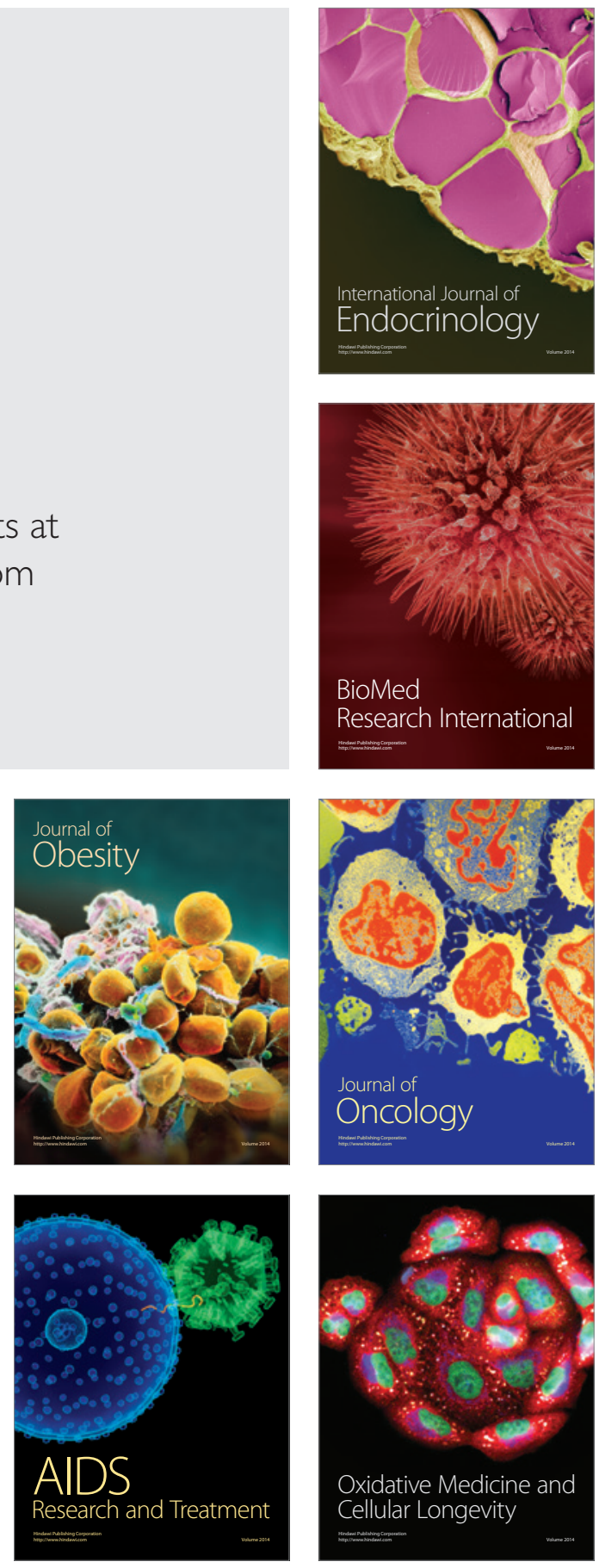